\title{
PRAXITELES' STATUE SET UP IN OLBIA PONTICA
}

Praxiteles' statue set up in the agora of Olbia Pontica probably was an Apollo. His configuration can be retrieved thanks to a statuette of Apollo now in Kiev. Praxiteles might have represented the god as archer. This statue should be included among the evidence of the appeal of Athenian visual arts in this city.

Keywords: Praxiteles, Olbia, Apollo Delphinios, Stratonides, Agora.

Антонио Корсо

(Kanellopoulos Foundation / Messenian Society, Афины, Греция)

\section{Статуя Праксителя, установленная в Понтийской Ольвии}

В статье выдвигается несколько предположений относительно не сохранившейся до настоящего времени статуи Праксителя, которая была установлена на агоре в Ольвии. Фрагменты постамента статуи, на которых достаточно хорошо сохра-

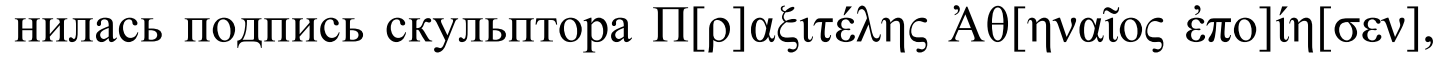
были в свое время обнаружены на территории агоры, однако в настоящее время их местонахождение неизвестно. Предполагается, что скульптура, относящаяся к 350 г. до н. э., изображала стреляющего из лука Аполлона. Это предположение автор статьи аргументирует анализом зафиксированных на остатках постамента фрагментов посвятительной надписи, а также сопоставлением с безголовой мраморной фигурой из Ольвии, находящейся в Киеве, вероятно уменьшенной копией утраченной скульптуры.

Ключевые слова: Пракситель, Ольвия, Аполлон Дельфийский, агора

The aim of this note is to put forward a few suggestions concerning a statue set up in the agora of Olbia Pontica and signed by the renowned late classical sculptor Praxiteles.

Fragments of the base of this statue were found in the area of the agora, but their present whereabouts are not known.

The following inscription was read on these fragments ${ }^{1}$ :

${ }^{1}$ See Latyschev 1916: 256-257, inscription number 271. 
]ОГ[

]ПО्[

] $\mathrm{IN}[$

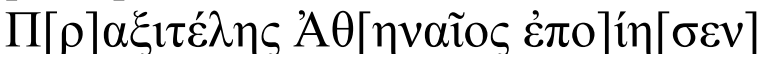

Most of the signature of the sculptor survives, only the $\rho$ of the name of Praxiteles was missing.

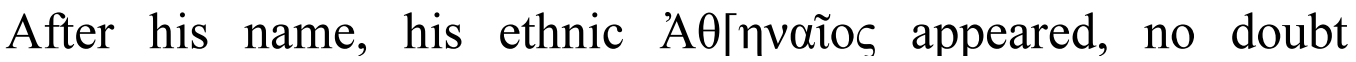
because the statue had to be set up far from Athens, thus the ethnic of this Athenian sculptor had to be specified.

Another fragment of the base bears the letters in, probably pertaining to the verb $\dot{\varepsilon} \pi \mathrm{o}] \dot{\eta}[\sigma \varepsilon v]$ which must have followed the ethnic.

The date of this inscription is around $350 \mathrm{BC}$.

The surviving letters of the dedication had the same size as the letters of the signature $(0,02 \mathrm{~m}$.): this observation implies that the status of this artist was highly regarded at Olbia and that the Olbians were proud to exhibit a statue made by him and thus gave to his signature the same importance and size, as assigned to the dedication.

A fragment of the dedication bears the letters $\Pi О$ which might suggest the mention of the subject of the statue: Apollo.

This god was the most important one of this Milesian colony ${ }^{2}$. His most significant sanctuary was on the Acropolis, where the monumental temple of Apollo Delphinios stood, at a short distance from the place in the agora where the above mentioned fragments of the base of Praxiteles' statue were found (fig. 1) ${ }^{3}$. Thus the topographical context strengthens the suggestion that Praxiteles' statue was an Apollo. Indeed, an agalma of this god set up in the agora in front of his main sanctuary in town makes sense.

Praxiteles may have made another Apollo for a Milesian colony: his Apollo Sauroctonus was probably set up in Apollonia ad Rhyndacum ${ }^{4}$.

${ }^{2}$ About Olbia and its cult of Apollo, see Christodoulou 2016: 215-242 with previous bibliography; Fornasier 2017: 241-270; Idem et alii, 2017 a, 19-61 and Guzman 2019: 601-619.

${ }^{3}$ See bibliography cited in note 2 and, besides, Kryžickij and Krapivina, 2001: 15-70, particularly 20; Skržinskaja 2004: 107-113; Lisový, 2004: 947-955; Braund 2007: 33-77; Bujskich 2009: 299-346 and Kryžickij 2011.

${ }^{4}$ See Corso 2020: 247-253. 
It is not impossible that the fame of the Sauroctonus among the Milesian communities of the Black Sea elicited the desire of the Olbians to emulate the Apollonians and to have a statue of their poliadic god made by the same master.

Al least from 437 BC, when Olbia joined the Delian League ${ }^{5}$, this city was receptive to the styles of the most important masters of the Greek mainland and of Athens in particular. In the late $5^{\text {th }}$ and early $4^{\text {th }}$ century $\mathrm{BC}$, the Pheidian style prevails in town while in the middle of the $4^{\text {th }}$ century BC the appeal of the Scopadic style is clear in the Olbian visual culture ${ }^{6}$. Thus, the reception of the art of Praxiteles is hardly surprising.

Another feature to keep in mind is that around $350 \mathrm{BC}$ Olbia enjoyed an economic boom ${ }^{7}$ : however very soon this prosperity would be challenged by the attempts of the kingdom of Macedonia to seize this city ${ }^{8}$.

Since Pliny 36. 22 and Pausanias 1. 20. 1-2 suggest that Praxiteles worked at Athens in his own workshop and that heralds of the patrons used to come to Athens even from far away in order to pick up statues made by him, it is likely that this statue, too, was carved in the Athenian workshop of the master and then shipped to Olbia.

A headless marble Apollo from Olbia (fig. 2) ${ }^{9}$ dated to late classical times may shed light upon this creation: the god was bent toward his right side, his left arm was lowered with his forearm forwarded while his right arm was uplifted, his right hand probably resting on his head. His mantel is thrown on his left shoulder and falls down from his left forearm. The position of the left forearm suggests that he held a bow in his left hand.

The surface reveals the typical Praxitelean prevalence of velvety skin upon muscles and bones in the anatomy.

These considerations suggest that the statuette depended on a 'model' which was marble and not bronze.

The sinuous configuration of the body was often adopted by our master. The right arm uplifted with the corresponding arm resting on

\footnotetext{
${ }^{5}$ See von Bredow 2007: 80-81.

${ }^{6}$ Evidence of the reception of the art of the great Greek masters at Olbia: see de Ballu 1972: 71-75.

${ }^{7}$ See Wasowicz 1975: 67-100.

${ }^{8}$ See von Bredow 2007: 80-81.

${ }^{9}$ See A. S. Rusyaeva 1992: 38-39, fig. 10 and Kryžickij and Krapivina 2001: 46-47: the statuette is kept in the Archaeological Museum of Kiev.
} 
the head had been adopted by Praxiteles for his Archer Eros (Callistratus 3. 3) ${ }^{10}$, whose general style was very similar to that of the Olbian Apollo. The drapery falling down from the left forearm characterized Praxiteles' Persephone kidnapped by Hades ${ }^{11}$, his Maenads $^{12}$, his Dionysos with the two Nikai ${ }^{13}$, his statues of Kore ${ }^{14}$, his Thespian Aphrodite to be recognized in the Arles type ${ }^{15}$, his Nymphs ${ }^{16}$, his Merry Courtesan ${ }^{17}$, of course his Cnidian Aphrodite $^{18}$, his Coan Aphrodite ${ }^{19}$, figures of his Dodekatheon ${ }^{20}$, his Apollo for Megara ${ }^{21}$, his Opora $^{22}$ and his Eros of Parium ${ }^{23}$. With few changes, this type will become the late classical Formiae type of Apollo $^{24}$, the Apollo Lyceius, although the latter had no drapery ${ }^{25}$, and an Apollo Cytharoedus ${ }^{26}$.

Thus, this Olbian Apollo is well inside the Praxitelean concept of general style and of anatomic grammar.

It should be noticed that archery was highly regarded at $\mathrm{Olbia}^{27}$ : that is obvious because this Greek colony was close to the Scythian world and archers were very appreciated in Scythian societies ${ }^{28}$.

Therefore, a statue of Apollo represented as archer should not be surprising at Olbia. There is a strong possibility that this statuette depends on Praxiteles' Apollo set up in the agora of Olbia.

\footnotetext{
${ }^{10}$ See A. Corso 2004, work no. 16.

${ }^{11}$ See Corso 2004, work no. 5.

${ }^{12}$ See Corso 2004, work no. 10.

${ }^{13}$ See Corso 2004, work no. 11.

${ }^{14}$ See Corso 2004, works nos. 12 and 13.

${ }^{15}$ See Corso 2004, work no. 17.

${ }^{16}$ See Corso 2004, work no. 19.

${ }^{17}$ See Corso 2004, work no. 20.

${ }^{18}$ See Corso 2007, work no. 22.

${ }^{19}$ See Corso 2007, work no. 23.

${ }^{20}$ See Corso 2007, work no. 24.

${ }^{21}$ See Corso 2010, work no. 27.

${ }^{22}$ See Corso 2010, work no. 32.

${ }^{23}$ See Corso 2013, work no. 37.

${ }^{24}$ See Corso 2013, work no. 48.

25 See Nagele 1984: 77-105.

${ }^{26}$ See M. Flashar 1992, figs. 94-95 and 102-103.

${ }^{27}$ See $e$. $g$. de Ballu 1972, fig. 13 and pls. 82 and 90.

${ }^{28}$ About the importance of bows and arrows in the interaction between the

Olbian society and the Scythian world, see $e$. $g$. Braund 2007, 37-77.
} 
This consideration leads to another suggestion: that Praxiteles' Apollo may have enjoyed a certain fame in town if shortly after its setting it was reproduced with the statuette now in Kiev.

Moreover, the presence of a statue of Apollo by the famous Athenian Praxiteles probably encouraged, in the third quarter of the $4^{\text {th }}$ century $\mathrm{BC}$, a prominent Olbian citizen, Leocrates, to commission a bronze statue of Apollo Iatros from another Athenian master, Stratonides ${ }^{29}$.

Finally, the appeal of Praxitelean creations at Olbia must have been strong at least until around $300 \mathrm{BC}$, when a local close variation of the Cnidian Aphrodite was dedicated ${ }^{30}$.

\section{Bibliography}

Braund, D. 2007: Greater Olbia. In: D. Braund (ed.) Classical Olbia. Oxford, 33-77.

Bujskich, S. B. 2009: Aus der Geschichte des religiösen Lebens griechischer Kolonisten im unteren Buggebiet. In: K. Stähler (ed.), Die Griechen und ihre Nachbarn am Nordrand des Schwarzen Meeres. Münster, 299-346.

Corso, A. 2004: The Art of Praxiteles 1. Rome.

Corso, A. 2007: The Art of Praxiteles II. Rome.

Corso, A. 2010: The Art of Praxiteles III. Rome.

Corso, A. 2013: The Art of Praxiteles IV. Rome.

Corso, A. 2020: The statue of Apollo Smintheus by Skopas and the monumental policy of the satrap Artabazus'. In: V. Keles (ed.). Propontis. Istanbul, 247-253.

Christodoulou, S. 2016: The History of ancient Olbia. Balkan Studies 51, 215-242.

de Ballu, E. B. 1972: Olbia. Leiden.

Flashar, M. 1992: Apollo Cytharoedus. Vienna.

Fornasier, J. 2017: Ein Stadtbild im Wandel: neue Ergebnisse eines deutsch-ukrainischen Forschungsprojektes aus der griechischen Kolonie Olbia Pontike. Das Altertum 62, 241-270.

Fornasier, J. et alii 2017a: Vor den Toren der Stadt: Deutsch-ukrainische Forschungen in der Vorstadt von Olbia Pontike. AA. 19-61.

Guzman, M. O. 2019: Les strategoi et le culte d'Apollon à Olbia du Pont. Nouvelles recherches prosopographiques'. In: V. Cojocaru et alii

\footnotetext{
${ }^{29}$ See Vollkommer 2004: 425-426 and Traill 2006: 452, no. 841760. Even in this case, the size of letters of the signature of the sculptor is the same of the letters of the dedication: see Kiripovic and Levi 1968, pl. 32, no. 65. Of course, this fact reflects the importance attributed to statues of Athenian masters in late classical Olbian society.

${ }^{30}$ See Corso 2007: 206-207, note 8, copy no. 3.
} 
(ed.). Advances in Ancient Black Sea Studies: Historiography, Archaeology and Religion. Cluj, 601-619.

Kiripovic, T. I., Levi, E. I. 1968: Inscriptiones Olbiae. Leningrad.

Kryžickij, S. D. 2011: Olbia : fouilles, histoire, culture. Paris.

Kryžickij, D., Krapivina, V. V. 2001: Olbia Pontica. In: E. Samaritaki (ed.). Ancient Greek Cities on the Northwest coast of the Black Sea. Kiev, 15-70.

Latyschev, B. 1916: Inscriptiones antiquae orae septentrionalis Ponti Euxini. Petropolis, vol. I ( $2^{\text {nd }}$ ed.).

Lisový, I. 2004: Die Göttinnen im antiken Nordosten des Schwarzen Meeres. In: H. Heftner (ed.). Ad fontes!: Festschrift für Gerhard Dobesch. Vienna, 947-955.

Nagele, M. 1984: Zum Typus des Apollon Lykeios. OeJ 55, 77-105.

Rusyaeva, A. S. 1992: Religiya i kulty antichnoi Olbii. Kiev.

Skržinskaja, M. V. 2004: Prazdniki Apollona na Bospore i v Ol'vii'. Archeologičeskie Vesti 11, 107-113.

Traill, J. S. 2006: Persons of ancient Athens. Toronto, 15.

Vollkommer, R. 2004: Stratonides. Künstlerlexikon der Antike 2, Munich, $425-426$

von Bredow, I. 2007: Olbia (1). In: Brill's New Pauly 10, 80-81.

Wasowicz, A. 1975: Olbia Pontique, Paris, 67-100.

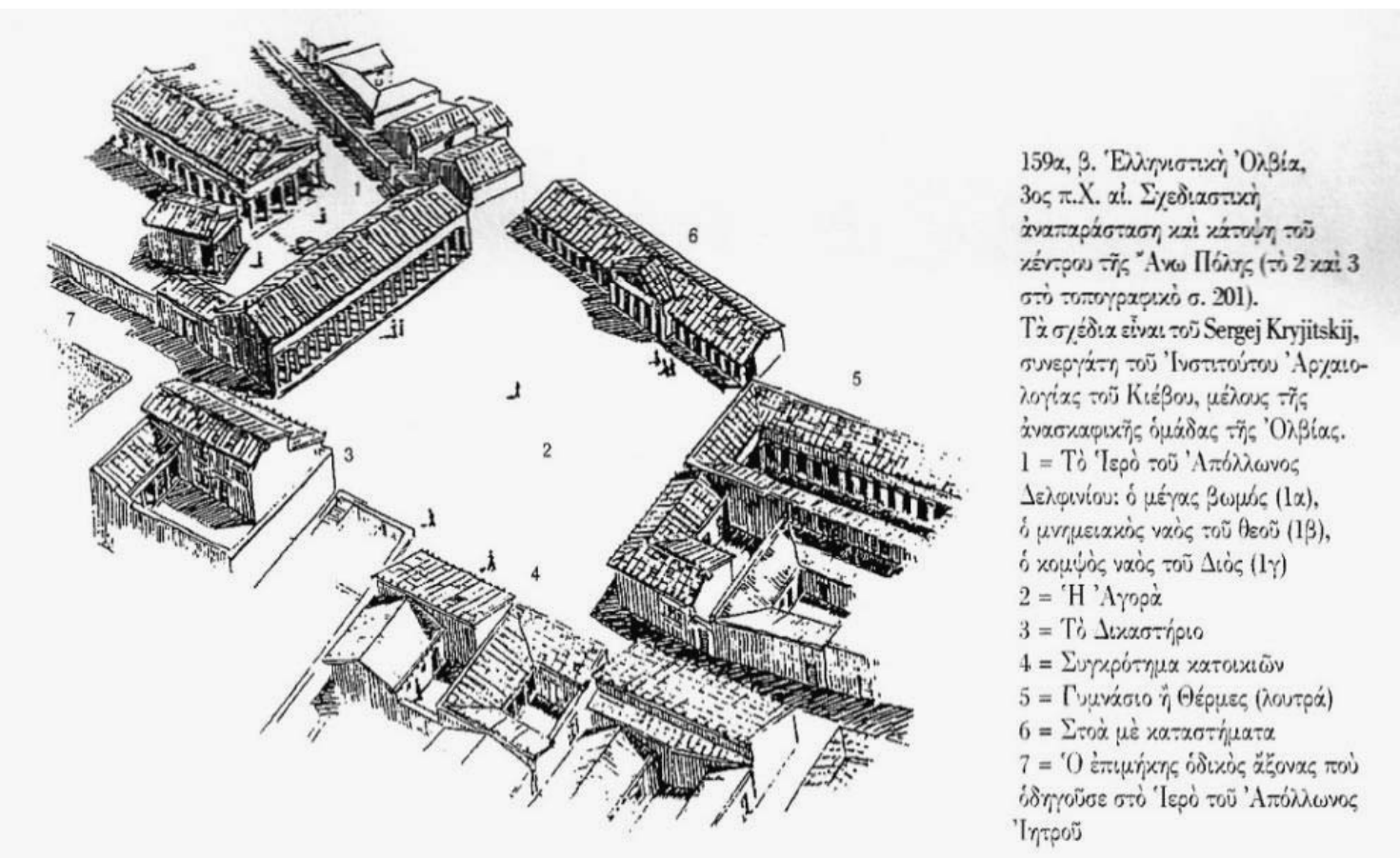

Fig. 1: Reconstruction drawing of the area of Olbia with the agora and the sanctuary of Apollo Delphinios (from Christodoulou, note 2). 


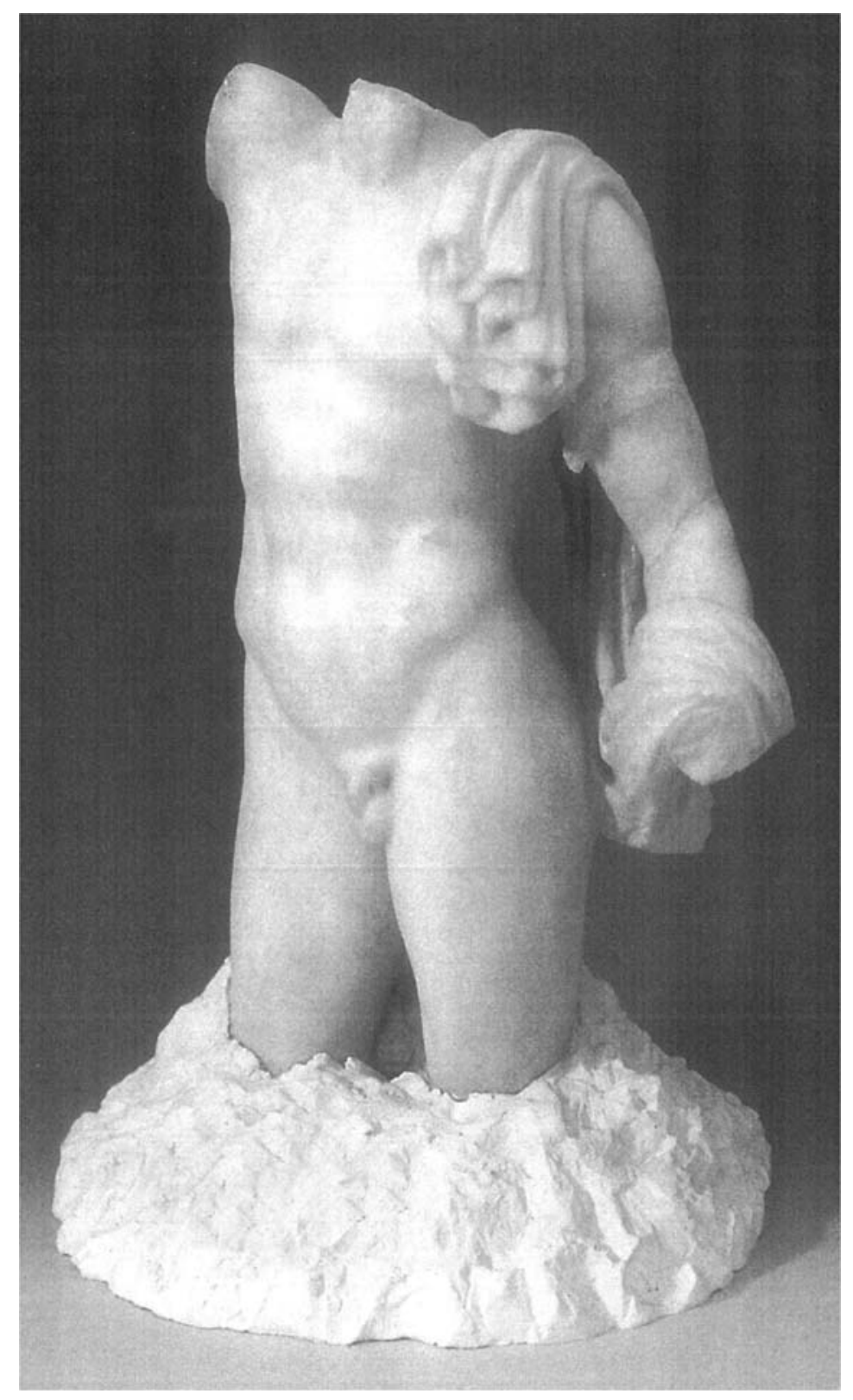

Fig. 2. Statuette of Apollo from Olbia at Kiev, Archaeological Museum. 